\title{
Mortality due to acquired immunodeficiency syndrome and associated social factors: a spatial analysis
}

\author{
Mortalidade pela síndrome da imunodeficiência adquirida e fatores sociais associados: uma análise espacial \\ Mortalidad por el síndrome de la inmunodeficiencia adquirida y factores sociales relacionados: un análisis espacial
}

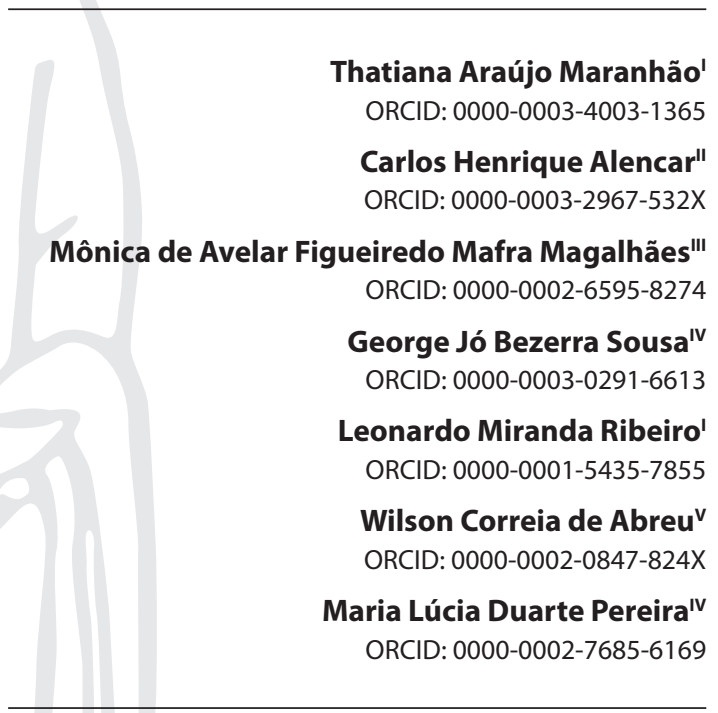

'Universidade Estadual do Piauí. Parnaíba, Piauí, Brazil. "Universidade Federal do Ceará. Fortaleza, Ceará, Brazil. II'Fundação Oswaldo Cruz. Rio de Janeiro, Rio de Janeiro, Brazil. " Universidade Estadual do Ceará. Fortaleza, Ceará, Brazil. $\checkmark$ Universidade do Porto. Porto, Portugal.

How to cite this article: Maranhão TA, Alencar CH, Magalhães MAFM, Sousa GJB, Ribeiro LM, Abreu WC, et al. Mortality due to acquired immunodeficiency syndrome and associated social factors: a spatial analysis.

Rev Bras Enferm. 2020;73(Suppl 5):e20200002. doi: http://dx.doi.org/10.1590/0034-7167-2020-0002

Corresponding author: Thatiana Araujo Maranhão E-mail: thatianamaranhao@phb.uespi.br

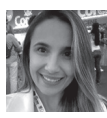

EDITOR IN CHIEF: Antonio José de Almeida Filho ASSOCIATE EDITOR: Alexandre Balsanelli

\section{ABSTRACT}

Objective: To analyze the spatial pattern of AIDS mortality and social factors associated with its occurrence. Methods: An ecological study that considered 955 AIDS deaths of residents in Piauí, reported in the Mortality Information System (MIS) from 2007 to 2015. Non-spatial and spatial regression models were used to identify social determinants of AIDS mortality, with a significance of $5 \%$. Results: The predictors of AIDS mortality were illiteracy rate in males $(p=0.020)$, proportion of households with water supply $(p=0.015)$, percentage of people in households with inadequate walls $(p=0.022)$, percentage of people in households vulnerable to poverty and in whom no one has completed primary education $(p=0.000)$ and percentage of people in households vulnerable to poverty and dependent on the elderly $(p=0.009)$. Conclusion: Social indicators related to education, job and income generation and housing were associated with AIDS mortality.

Descriptors: HIV; Acquired Immunodeficiency Syndrome; Mortality; Social Determination of Health; Spatial Analysis.

\section{RESUMO}

Objetivo: Analisar o padrão espacial da mortalidade por aids e fatores sociais associados à sua ocorrência. Métodos: Estudo ecológico que considerou 955 óbitos por aids de residentes no Piauí, notificados no Sistema de Informações sobre Mortalidade (SIM) de 2007 a 2015. Modelos de regressão não espacial e espacial foram usados para identificar determinantes sociais da mortalidade por aids, com significância de $5 \%$. Resultados: As variáveis preditoras da mortalidade por aids foram taxa de analfabetismo no sexo masculino $(p=0,020)$ proporção de domicílios com abastecimento de água $(p=0,015)$, percentual de pessoas em domicílios com paredes inadequadas $(p=0,022)$, percentual de pessoas em domicílios vulneráveis à pobreza e em que ninguém tem ensino fundamental completo $(p=0,000)$ e percentual de pessoas em domicílios vulneráveis à pobreza e dependentes de idosos ( $p=$ 0,009 ). Conclusão: Foram associados à mortalidade por aids indicadores sociais relacionados à educação, geração de emprego e renda e habitação.

Descritores: HIV; Síndrome da Imunodeficiência Adquirida; Mortalidade; Determinação Social da Saúde; Análise Espacial.

\section{RESUMEN}

Objetivo: Analizar el estándar espacial de la mortalidad por sida y factores sociales relacionados a su ocurrencia. Métodos: Estudio ecológico que consideró 955 óbitos por sida de residentes en Piauí, notificados en el Sistema de Informaciones sobre Mortalidad (SIM) de 2007 a 2015. Modelos de regresión no espacial y espacial han sido usados para identificar determinantes sociales de la mortalidad por sida, con significación de $5 \%$. Resultados: Las variables indicadoras de la mortalidad por sida han sido tasa de analfabetismo en el sexo masculino $(p=0,020)$ proporción de domicilios con abastecimiento de agua $(p=0,015)$, porcentual de personas en domicilios con paredes inadecuadas $(p=0,022)$, porcentual de personas en domicilios vulnerables a la pobreza y en que ninguno tiene enseñanza fundamental completa $(p=$ 0,000 ) y porcentual de personas en domicilios vulnerables a la pobreza y dependientes de ancianos $(p=0,009)$. Conclusión: Han sido relacionados a la mortalidad por sida indicadores sociales relacionados a la educación, generación de empleo y renta y habitación. Descriptores: $\mathrm{VIH}$; Síndrome de la Inmunodeficiencia Adquirida; Mortalidad; Determinación Social de la Salud; Análisis Espacial. 


\section{INTRODUCTION}

Since the beginning of the HIV / AIDS epidemic, more than 35 million people have died worldwide ${ }^{(1)}$. Of these, about 316 thousand occurred in Brazil. After the institution of the policy that provides antiretroviral treatment (ART) regardless of the immune status of the person living with HIV / AIDS (PLWHA), there was a $7.2 \%$ reduction in the mortality rate in the 2014-2015 biennium. However, this drop was not verified in all Brazilian regions, given that in the North and Northeast the coefficients increased by $7.6 \%$ and $2.3 \%$, respectively, demonstrating the tendency of growth of mortality in the last ten years in these regions $s^{(2)}$.

Study that compared the HIV / AIDS mortality coefficients of the Brazilian states, based on data provided by the Department of STD / AIDS and Viral Hepatitis of the Ministry of Health (DSAVH / MH) and the study of disease loads 2015 (GBD 2015), pointed to a significant increase in deaths in several federative units. Based on the information from the DSAVH/MH, the authors calculated that from 2000 to 2014, in 12 states in Brazil, mortality from HIV/ AIDS increased by more than $50 \%$, ranging from $52 \%$ in Bahia to $875 \%$ in Amapá. More specifically in the state of Piauí, the increase in deaths in this period was $140 \%$ since, in 2000 , the mortality coefficient was 1.5 deaths / 100,000 inhabitants and jumped to 3.6 deaths / 100,000 inhabitants in 2014 (3).

Most people who die from AIDS-related causes are adults at the height of their productive phase ${ }^{(2)}$, which translates not only a public health problem, but also a challenge for the other economic sectors of society. The magnitude of this problem raises the need to study social aspects that may interfere with the panorama of the disease and related deaths ${ }^{(4)}$. Research points to several indicators that translate the living conditions of the population of a territory and have a significant role both in determining HIV infection and in illness and mortality from AIDS, such as: unemployment, access to health services, education, housing conditions and basic sanitation ${ }^{(5-6)}$, however, no such research has been carried out in Piauí.

The populations have social compositions that show disparities; thus, patterns of HIV / AIDS morbidity and mortality do not occur randomly in space, but in orderly patterns that express underlying causes. In this scenario, it is assumed that the determinants of the health-disease process observed in one geographic territory may not be observed in others and vice versa. Therefore, it would only be possible to generalize the results to similar populations, but there is still the risk that one or another social determinant may not be applicable ${ }^{(7)}$. In view of this, spatial analysis proves to be effective in identifying geographic patterns and social determinants of health related to mortality from HIV / AIDS, more appropriately supporting intersectoral interventions on these specific factors in order to stop the infection cycle and death in the territories.

\section{OBJECTIVE}

Analyze the spatial pattern of AIDS mortality and social factors associated with its occurrence.

\section{METHODS}

\section{Ethical aspects}

All ethical and legal aspects recommended by Resolution $466 / 12$ were respected. The collection of information took place at SES-PI in a confidential manner, omitting the identification of individuals. This study was submitted to and approved by the Research Ethics Committee of the State University of Piauí.

\section{Type, study location and period}

This is an ecological study, carried out according to the guidelines of the STROBE instrument, in which the deaths from AIDS that occurred from 2007 to 2015 in Piauí, state of the Northeast of Brazil were spatially analyzed. It should be noted that the larger project of which this study is part encompassed not only deaths, but also AIDS cases. Thus, in view of the fact that AIDS notifications were also the object of study, we opted for the uniform collection of cases and deaths that occurred since 2007, because, in the same year, Sinan Net, a new information from the Ministry of Health, replacing Sinan Windows, in effect until 2006, whose variables differed somewhat from those in the version since 2007. The time span was until 2015, since data collection took place in October 2016.

Although only 110 of the 224 municipalities in Piauí registered at least one death due to causes related to HIV / AIDS in the period studied, all municipalities in the state, in this investigation, were included in the spatial analysis. It is noteworthy that the average population of the municipalities in Piauí is 14,075 inhabitants (standard deviation $=56,022$ ), with the municipalities of Teresina and Miguel Leão having the largest $(822,364)$ and smallest $(1,239)$ number of inhabitants in the state, respectively.

Figure 1 shows that Piauí is divided into four development mesoregions: North Piauí, Center-North Piauí, Southeast Piauí and Southwest Piauí. The polygon that corresponds to the capital Teresina is highlighted in the Center-North mesoregion.
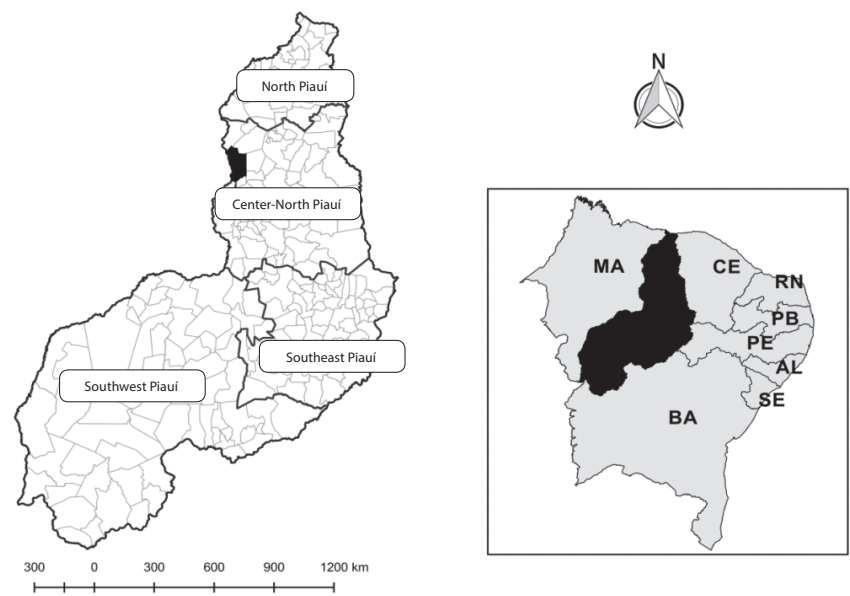

Figure 1 - Division of Piauí in development mesoregions, with emphasis on the capital Teresina and the location of the state in Northeast Brazil 


\section{Population, sample and inclusion and exclusion criteria}

During the period studied, 959 deaths from the disease occurred in Piauí, however four were discarded from the spatial analysis because they did not contain information about the municipality of residence. Therefore, the sample universe of this investigation corresponded to 955 AIDS deaths among individuals residing in the state registered in the Mortality Information System (MIS). The Piauí State Department of Health (SES-PI) made the death databases registered in the SIM available and only information was collected from those who mentioned AIDS in the basic cause of death certificates, that is, when the B20 codes to B24 were cited according to the 10th International Classification of Diseases (ICD-10).

\section{Study protocol}

Socioeconomic data were obtained from the 2010 Demographic Census, available on the website of the Brazilian Institute of Geography and Statistics ${ }^{(8)}$. For each municipality, 43 socioeconomic indicators were collected, among them, those included in this study: Illiteracy rate in males; Early school leaving rate; Proportion of adequate housing; Proportion of households with a water supply network; Proportion of households without sanitation; Percentage of people in households with inadequate walls; Average number of residents per household; Proportion of own households; Percentage of people in households vulnerable to poverty and in whom no one has completed elementary school; Percentage of people aged 15 to 24 who do not study or work and are vulnerable to poverty; Percentage of people in households vulnerable to poverty and dependent on the elderly.

\section{Analysis of results and statistics}

The AIDS mortality coefficient for each municipality was calculated using the software TabWin v.4.14 ${ }^{\circ}$. In order to minimize the instability of crude rates and correct random fluctuations that occur especially in municipalities with a small number of inhabitants, the Bayesian Local Empirical method was used ${ }^{(7)}$. Such an estimate was necessary due to the low population density in the state of Piauí (12.40 inhabitants / $\left.\mathrm{km}^{2}\right)^{(9)}$.

Then, the transformation of the Neperian logarithm (Ln) type was applied to the Bayesian mortality rate to approximate the values to a normal distribution, which is a prerequisite for adjustment to the spatial regression model ${ }^{(10)}$.

The presence of correlation between the independent variables (socioeconomic) and the dependent variable (logarithm of the AIDS mortality rate after Bayesian smoothing) was verified using the Variance Inflation Factor (VIF), selecting them by the backward method and epidemiological criteria. Those with a correlation coefficient less than $0.7^{(10)}$ were included in the multivariate linear regression model (Ordinary Least Squares Estimation - OLS).

Thus, the socioeconomic variables that best explained the occurrence of AIDS mortality in Piauís territory were sought with a statistical significance of 95\%. However, since the classic OLS model does not take into account in its adjustment the spatial location of the studied phenomenon, the geographically weighted spatial regression model (Geographically Weighted Regression - GWR) was applied to the statistically significant explanatory variables in the OLS model, seen that mortality and its determinants vary according to the area in which they are studied ${ }^{(11)}$. The best adjustment of the OLS and GWR models occurred through two parameters: lower value of the Akaike information criterion (AIC) and higher value of the determination coefficient $\left(R^{2}\right)$.

The statistical significance of the parameters of the GWR model was verified by the Wald test and by means of two thematic maps. The first map, in green tones, shows the distribution of the parameter estimates. Municipalities in lighter green tones have a negative association, with the highlighted variable being a protective factor. The cities in darker green have a positive association with the represented variable, consisting of a risk factor for AIDS mortality. The second map, in shades of gray, represents the statistical significance of the Wald test performed for each parameter, having been classified as 99\%, 95\%, 90\% confidence and not significant.

The GeoDa software v.1.12 ${ }^{\circledR}$ was used to calculate Bayesian statistics. The transformation of the Neperian logarithm type of the Bayesian mortality rate and the adjustment of the GWR and OLS models were made in the software $R$ version $3.3 .3^{\circledR}$, and the construction of the maps derived from these analyzes were made in the software ArcGis 10.2.2.

\section{RESULTS}

A total of 959 AIDS deaths were registered distributed in $48.6 \%$ of the municipalities in Piauí. Mortality presented a cyclical trend with peaks in each studied triennium (2009, 2012 and 2015). The highest mortality was registered in 2012 (4.3 deaths / 100,000 inhabitants), and the average rate in the analyzed period was 3.36 deaths / 100,000 inhabitants (Figure 2).

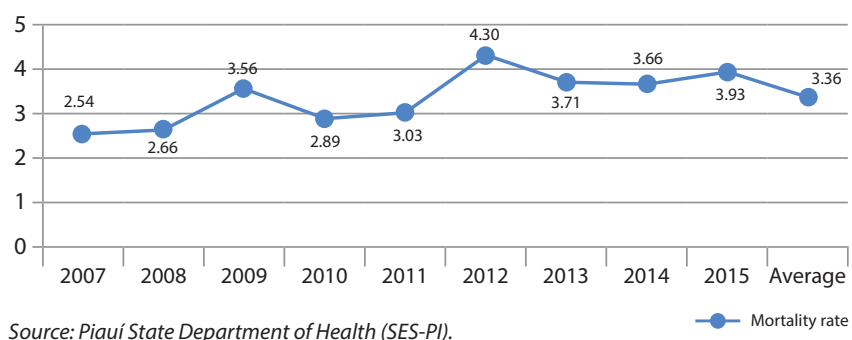

Source: Piaui State Department of Health (SES-PI).

Figure 2 - AIDS mortality coefficient, Piauí, Brazil, 2007-2015

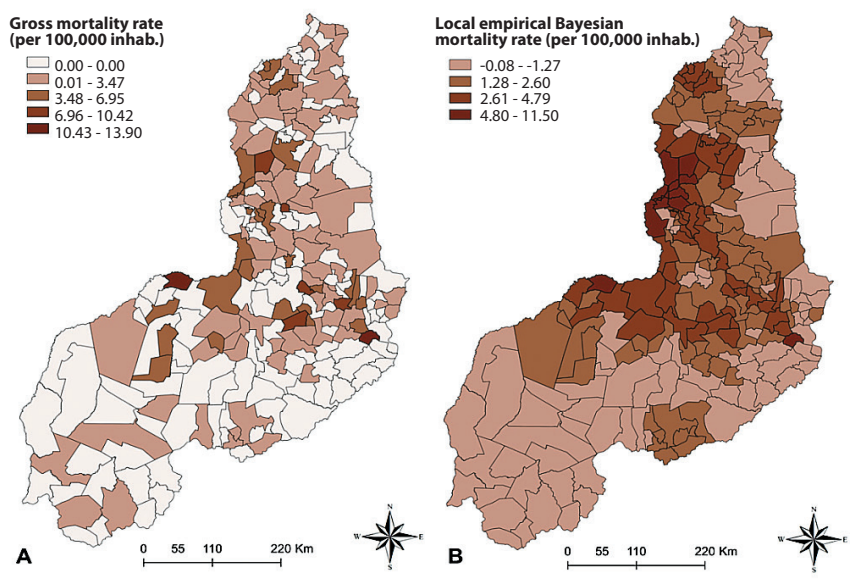

Figure 3 - Spatial distribution of the crude mortality rate $(A)$ and smoothed by the local empirical Bayesian method (B), Piauí, Brazil, 2007-2015 
Table 1 - Ordinary Least Squares Estimation - OLS regression model for the logarithm of the AIDS mortality rate after Bayesian smoothing, Piauí, Brazil, 2007-2015

\begin{tabular}{|c|c|c|c|c|}
\hline Variables & Estimate & $\begin{array}{l}\text { Standard } \\
\text { deviation }\end{array}$ & $\begin{array}{c}\text { Value } \\
\text { of } t\end{array}$ & $\operatorname{Pr}(>|t|)$ \\
\hline Intercept & 3.6199 & 1.6517 & 2.1920 & 0.029 \\
\hline Illiteracy rate in males & 0.0273 & 0.0117 & 2.3390 & 0.020 \\
\hline Early school leaving rate & 0.0151 & 0.0103 & 1.4680 & 0.143 \\
\hline Proportion of suitable housing & -0.0107 & 0.0065 & -1.6410 & 0.102 \\
\hline $\begin{array}{l}\text { Proportion of households with water } \\
\text { supply }\end{array}$ & 0.0090 & 0.0037 & 2.4350 & 0.015 \\
\hline $\begin{array}{l}\text { Proportion of households without } \\
\text { sanitation }\end{array}$ & -0.0091 & 0.0061 & -1.4830 & 0.139 \\
\hline $\begin{array}{l}\text { Percentage of people in households with } \\
\text { inadequate walls }\end{array}$ & 0.0109 & 0.0048 & 2.2920 & 0.022 \\
\hline $\begin{array}{l}\text { Average number of residents per } \\
\text { household }\end{array}$ & -0.4443 & 0.2889 & -1.5380 & 0.125 \\
\hline Proportion of own households & -0.0203 & 0.0120 & -1.6950 & 0.091 \\
\hline $\begin{array}{l}\text { Percentage of people in households } \\
\text { vulnerable to poverty and in whom no one } \\
\text { has completed primary education }\end{array}$ & -0.0470 & 0.0117 & -4.0220 & 0.000 \\
\hline $\begin{array}{l}\text { Percentage of people aged } 15 \text { to } 24 \text { who } \\
\text { do not study or work and are vulnerable } \\
\text { to poverty }\end{array}$ & -0.0204 & 0.0122 & -1.6720 & 0.096 \\
\hline $\begin{array}{l}\text { Percentage of people in households } \\
\text { vulnerable to poverty and dependent on } \\
\text { the elderly }\end{array}$ & 0.1034 & 0.0394 & 2.6230 & 0.009 \\
\hline
\end{tabular}

The spatial distribution of the gross mortality rate shows that the epidemic is present beyond the state capital and metropolitan region, affecting small towns and distant from large urban centers (Map 2A). The smoothed map shows the highest rates in municipalities on the border with Maranhão, close to the state capital, with mortality above 4.80 deaths / 100,000 inhabitants, as highlighted in Map 2B (Figure 3).

The linear regression model (OLS) pointed out the following variables as predictors of AIDS mortality in Piauí: male illiteracy rate $(p=0.020)$, proportion of households with a water supply network $(p=0.015)$, percentage of people in households with inadequate walls ( $p=0.022$ ), percentage of people in households vulnerable to poverty and in which no one has completed elementary school ( $p=$ 0.000 ) and percentage of people in households vulnerable to poverty and dependent on the elderly $(p=0.009)$ (Table 1). In OLS, the determination coefficient (R2) was 0.2343 and the Akaike information criterion (AIC) was 603.7670 .

Then, the spatial regression model (GWR) of the logarithm of the Bayesian mortality rate from AIDS was adjusted for the variables that were significant in the OLS model (Figure 3). When comparing the two regression models, it was observed that the GWR proved to be better adjusted than the OLS model, as it presented AIC of 508.8514 (inferior to OLS) and $\mathrm{R}^{\wedge^{2}}$ of 0.5620 (superior to that obtained by OLS ).

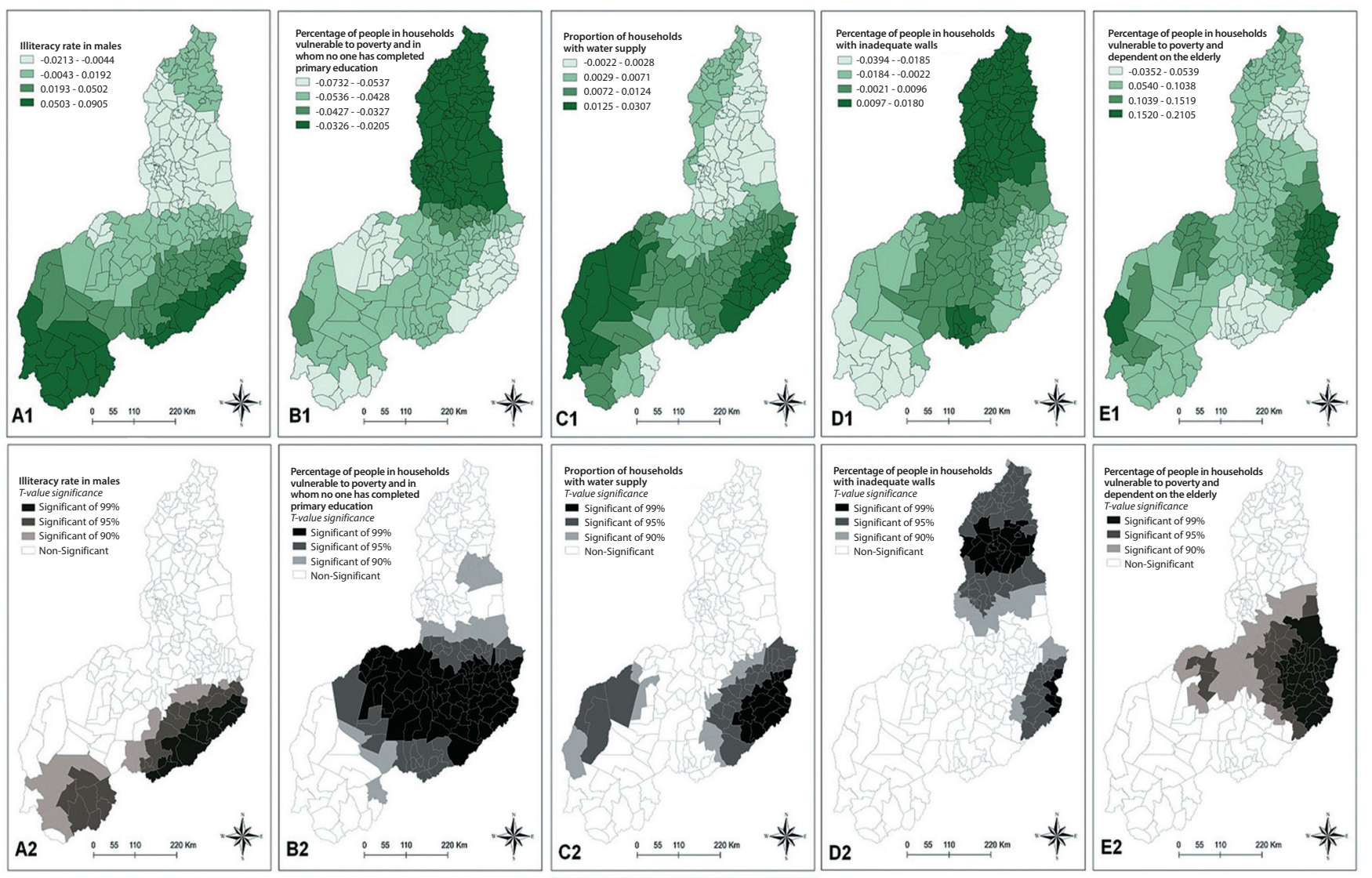

Figure 4 - Spatial distribution of the estimated coefficients and the significance of the t-value associated with the statistically significant independent variables in the OLS and Geographically Weighted Regression - GWR models, 07-2015 
Figure 4 shows the contribution of socioeconomic variables on AIDS mortality in Piauí's municipalities. Maps 3A1 and 3A2 show that, in the Southwest and Southeast mesoregions, the male illiteracy rate has a positive and significant association with the dependent variable. This demonstrates that the greater the illiteracy in males, the greater the logarithm of the Bayesian mortality rate for AIDS in these areas. Conversely, in some municipalities in the Central-North mesoregion, across the Southeastern mesoregion and part of the Southwest, the greater the percentage of people in households vulnerable to poverty and in which no one has completed elementary school, the lower the logarithm of the rate of Bayesian mortality from AIDS (Maps 3B1 and 3B2).

In municipalities in the southeastern mesoregion, as well as in municipalities in the Southwest of Piaui, close to the state of Maranhão, the greater the proportion of households with a water supply network, the greater the logarithm of the Bayesian mortality rate from AIDS (Maps 3C1 and 3C2). In the municipalities of the central-northern and northern regions of Piauí, it was found that the percentage of people in households with inadequate walls was shown to be a risk factor for AIDS mortality. On the other hand, in some municipalities in the Southeast mesoregion, on the border with the state of Pernambuco and the south of the state of Ceará, the same variable is a protective factor (Maps 3D1 and 3D2).

A significant positive association was observed between the variable "percentage of people in households vulnerable to poverty and dependent on the elderly" and the AIDS mortality rate, located in cities in the Southwest Piauí, from the border with the state of Maranhão, continuing continuously through several municipalities in the state and up to the central-north and southeast regions, on the borders with the states of Pernambuco and southern Ceará (Maps 3E1 and 3E2).

\section{DISCUSSION}

Smoothed maps indicate that the capital Teresina and some surrounding municipalities had the highest AIDS mortality rates. The epidemiological situation in the state capital is of particular concern, since its mortality rate was 7.9 deaths / 100,000 inhabitants, a figure almost twice as high as the average in Piauí (3.6 deaths / 100,000 inhabitants), and higher than that of the Northeast. (4.6 deaths / 100,000 inhabitants) and Brazilian (5.6 deaths / 100,000 inhabitants) ${ }^{(12)}$.

Although Brazil has public policies and programs for specialized monitoring of PLWHAs installed in capitals and cities in the interior of the states, the most complex health care and social networks in Piauí are predominantly concentrated in the capital. Thus, it is inferred that the most significant cluster of deaths in this territory is due to the immigration of individuals from municipalities in the interior of Piauí or even from other states in order to be accompanied by more complex services when the disease is already installed and subsequently evolves to death. Furthermore, if there are more cases of AIDS in the state capital compared to the interior ${ }^{(12)}$, more deaths are expected to occur where there are more people with the disease.

It was observed that, in several municipalities in the Southwest, Southeast and Center-North regions of Piauí, the illiteracy rate in males was shown to be a risk factor for AIDS deaths. A study conducted in South Africa pointed out that schooling is a protective effect against AIDS mortality, as it reduces the risk of death among individuals with ten or more years of education ${ }^{(13)}$.

It is well established in the literature that the level of education of PLWHA is an important predictor of adherence to ART ${ }^{(14-}$ ${ }^{15)}$ and the early virological response among those who initiate $\mathrm{it}^{(16)}$. A study carried out in Salvador, capital of the state of Bahia, estimated that HIV positive people with less than eight years of study are 2.2 times more likely to fail to adhere to ART compared to those with eight years of study or more, predisposing them to development of AIDS and death from related causes ${ }^{(14)}$.

In contrast, in a significant portion of the state's municipalities, the higher the percentage of people living in households vulnerable to poverty and where no one has completed elementary school, the lower the AIDS mortality rate. Although these results contradict most national studies, they strongly corroborate numerous published studies with data from Sub-Saharan Africa that point to the HIV / AIDS epidemic associated with better socioeconomic status and higher education ${ }^{(5,17-18)}$. According to research conducted in Malawi, wealthier and more educated men tend to have more partners and not to use condoms during sexual intercourse. As a result, those with greater purchasing power are more likely to become infected with the HIV virus and die from AIDS-related causes when compared to less educated and poorer individuals ${ }^{(18)}$.

In turn, the percentage of people living in households vulnerable to poverty and dependent on the elderly was a risk factor for AIDS mortality in municipalities in the Southeast, Southwest and Center-North Piauí. Research carried out in the state of Minas Gerais found that $56.9 \%$ of the interviewed families had the retirement of their elderly as the only source of income. Such results demonstrate the economic dependence on the income of the elderly and, for many families, what should be a "financial aid" becomes an essential income for survival. When the elderly die, entire families are disrupted and end up in extreme poverty ${ }^{(19)}$.

Therefore, the intimate relationship between mortality and socioeconomic status is emphasized, since people's longevity goes in the same direction as their living conditions. With regard to deaths from AIDS-related causes, it is no different. Investigations have already demonstrated the inverse relationship between HIV / AIDS mortality and socioeconomic status both at a country's macro-structural level $\mathrm{s}^{(20)}$ and at the individual or family level ${ }^{(21-22)}$. A systematic review with research carried out in South Africa showed that people with low socioeconomic status have a $50 \%$ higher risk of dying from HIV / AIDS, demonstrating the need to identify effective strategies that involve all sectors of society to reduce deaths among poorest infected ${ }^{(21)}$.

Two indicators related to housing conditions were also observed as associated with AIDS mortality in Piauí municipalities. In municipalities in the Southeast and Southwest mesoregions, the decrease in the proportion of households with water supply influences the reduction in AIDS mortality. This controversial result is justified by the low population occupation of rural areas, especially in Piauí, where the average demographic density is low $\left(12.40 \text { inhabitants } / \mathrm{km}^{2}\right)^{(9)}$. In these places, the installation of sewage and water supply networks is less suitable due to the low density of the buildings, and the adoption of individual sanitation solutions such as artesian wells and septic tanks is 
adequate. Thus, the absence of water and sewage installations does not necessarily mean that these locations are precarious ${ }^{(23)}$.

The percentage of people in households with inadequate walls was shown to be a risk factor for AIDS mortality in the CenterNorth and Piauiense North. Research has shown the quality of housing as a significant predictor of HIV / AIDS infection and mortality ${ }^{(6,24)}$, because one in three PLWHAs in the world live in structurally inadequate and / or overcrowded housing ${ }^{(25)}$. Poverty is primarily responsible for poor housing conditions, which in turn significantly interfere with the immunity of PLWHA, whose immune system is already compromised. Such a problem substantially affects the health outcomes of these vulnerable people and can lead to death ${ }^{(25-26)}$.

In a survey conducted in Ghana, the majority of HIV-positive people interviewed lived in deteriorated housing with serious problems in their physical structure, which subjected them to overcrowding and flooding. The results of this study show that the housing situations of seropositive individuals are determinants of their physical and mental states, which, in turn, influence the progression to AIDS and mortality due to diseases related to it ${ }^{(25)}$.

However, in some municipalities in the Southeast mesoregion, on the border with Pernambuco and southern Ceará, living in houses with inadequate walls is a protective factor against AIDS mortality. In a study carried out in rural Malawi, HIV / AIDS infection was positively associated with the wealth of families, measured by variables that denoted the population's living conditions, including the type of material used for the construction of homes. It was found that men who lived in brick houses were twice as likely to be infected by the virus compared to those who lived in houses built on earth and mud, materials still widely used in African buildings ${ }^{(18)}$.

In view of the above, the relationship between better or worse living conditions and HIV / AIDS infection and mortality does not always act in the same direction in all regions, being, therefore, heterogeneous and varying from one place to another. As such, wealth and poverty can lead to potentially risky or protective behaviors, being highly context specific and susceptible to change ${ }^{(27)}$.

The comparison of the paradoxical results of this study with data from research conducted in Africa is relevant, considering that, although they are geographically distant areas, some socioeconomic data, such as the HDI and the Gini index, of the African continent and the state of Piauí are similar ${ }^{(28-29)}$. Such similarities lead to infer that some characteristics of the social dynamics of HIV/AIDS infection that occur in specific regions of Piauí may be similar to those observed in the African continent.

\section{Study limitation}

This study has some limitations that, however, do not make it unfeasible. The main one refers to the use of secondary data, which may present inconsistencies regarding the quantity and quality of information. In addition, mortality data obtained from the MIS may present the incorrect classification of the underlying cause and underreporting of deaths due to AIDS-related causes.

\section{Contributions to the area of Nursing, Health or Public Policy}

Among the positive aspects of this study, the spatial regression method used stands out, which is still little explored in the literature. It takes into account the geographic location of the phenomenon, and is therefore more accurate than classical nonspatial regression models. When compared to the OLS model, the GWR facilitated the understanding of the relationship between the socioeconomic indicators in Piauí and the state epidemic, since it assumes the condition of dependence between observations. On the other hand, non-spatial models are not able to determine the relationship between the variables studied when the relationship is positive in some municipalities and negative in others. Furthermore, one cannot ignore the novelty of the investigation, as it is the first research on the spatial distribution of AIDS and its social determinants conducted in Piauí.

\section{CONCLUSION}

Social indicators that translate educational, housing and job and income generation conditions were shown to be positively or negatively associated with AIDS mortality in a significant portion of Piauí's municipalities. In view of these results, it is concluded that the control of the epidemic and related deaths is not the exclusive responsibility of the health field, as it is part of the broad spectrum of a territory's development agenda; therefore involves the most diverse sectors of society. Therefore, it is important to emphasize the need for interventions on the social determinants of health in specific municipalities as efficient methods of preventing HIV infection, illness and mortality from the disease, in addition to the already known programmatic interventions typical of the health sector.

\section{FUNDING}

Coordenação de Aperfeiçoamento de Pessoal de Nível Superior (CAPES) e Fundação de Amparo à Pesquisa do Estado do Piauí (FAPEPI).

\section{REFERENCES}

1. Joint United Nations Programme on HIV/AIDS (UNAIDS). Fact Sheet: World aids day 2017[Internet] Geneva: UNAIDS; 2017 [cited 2018 Feb 13]. Available from: http://www.who.int/news-room/detail/01-12-2017-world-aids-day-2017

2. Ministério da Saúde (BR), Secretaria de Vigilância em Saúde, Departamento de IST, Aids e Hepatites Virais. Boletim epidemiológico: HIV/ aids[Internet] Brasília (DF): Ministério da Saúde; 2017 [cited 2018 Feb 16]. Available from: http://www.aids.gov.br/pt-br/pub/2017/ boletim-epidemiologico-hivaids-2017

3. Guimarães MDC, Carneiro M, Abreu DMX, França EB. HIV/AIDS Mortality in Brazil, 2000-2015: Are there reasons for concern? Rev Bras Epidemiol. 2017;20(Suppl 1):182-90. doi: 10.1590/1980-5497201700050015 
4. Cunha GH, Fiuza MLT, Gir E, Aquino OS, Pinheiro AKB, Galvão MTG. Quality of life of men with AIDS and the model of social determinants of health. Rev Latino-Am Enfermagem. 2015;23(2):183-91. doi: 10.1590/0104-1169.0120.2541

5. Lakew Y, Benedict S, Haile D. Social determinants of HIV infection, hotspot areas and subpopulation groups in Ethiopia: evidence from the National Demographic and Health Survey in 2011. BMJ Open. 2015;5(11):1-11. doi: 10.1136/bmjopen-2015-008669

6. Aidala AA, Wilson MG, Shubert V, Gogolishvili D, Globerman J, Rueda S, et al. Housing status, medical care, and health outcomes among people living with HIV/AIDS: a systematic review. Am J Public Health. 2016;106(1):1-23. doi: 10.2105/AJPH.2015.302905

7. Ministério da Saúde (BR). Abordagens Espaciais na Saúde Pública[Internet] Brasília (DF): Ministério da Saúde; 2006 [cited 2018 Apr 14]; 135 p. Available from: http://bvsms.saude.gov.br/bvs/publicacoes/serie_geoproc_vol_1.pdf

8. Instituto Brasileiro de Geografia e Estatística (IBGE). Censo demográfico 2010. [Internet] Brasília (DF): IBGE; 2010 [cited 2018 mar 13$].$ Available from: http://censo2010.ibge.gov.br/

9. Fundação Centro de Pesquisas Econômicas e Sociais do Piauí (CEPRO). Piauí em números[Internet]. 10. ed. Teresina: Fundação CEPRO; 2013[cited 2018 Mar 15]. 101 p. Available from: http://www.cepro.pi.gov.br/piemnumeros.php

10. Magalhães MAFM, Medronho RA. Spatial analysis of Tuberculosis in Rio de Janeiro in the period from 2005 to 2008 and associated socioeconomic factors using micro data and global spatial regression models. Ciênc Saúde Coletiva. 2017;22(3):831-40. doi: 10.1590/1413-81232017223.24132015

11. Charlton M, Fotheringham S, Brunsdon C. Geographically Weighted Regression[Internet]. United Kingdon: ESRC National Centre for Research Methods; 2005 [cited 2018 Mar 15]. 30 p. Available from: http://eprints.ncrm.ac.uk/90/1/MethodsReviewPaperNCRM-006.pdf

12. Ministério da Saúde (BR), Secretaria de Vigilância em Saúde, Departamento de IST, Aids e Hepatites Virais [Internet]. Boletim epidemiológico: HIV/aids. Brasília (DF): Ministério da Saúde; 2016[cited 2018 Mar 16]. Available from: http://www.aids.gov.br/pt-br/ pub/2016/boletim-epidemiologico-de-aids-2016

13. Mee P, Collinson MA, Madhavan S, Kabudula C, Gómez-Olivé FX, Kahn K, et al. Determinants of the risk of dying of HIV/AIDS in a rural South African community over the period of the decentralised roll-out of antiretroviral therapy: a longitudinal study. Glob Health Action. 2014;20(7):1-14. doi: 10.3402/gha.v7.24826

14. Silva JAG, Dourado I, Brito AM, Silva CAL. Factors associated with non-adherence to antiretroviral therapy in adults with AIDS in the first six months of treatment in Salvador, Bahia State, Brazil. Cad Saúde Pública. 2015;31(6):1188-98. doi: 10.1590/0102-311X00106914

15. Foresto JS, Melo ES, Costa CRB, Antonini M, Gir E, Reis RK. Adherence to antiretroviral therapyby people living with HIV/AIDS in a municipality of São Paulo. Rev Gaúcha Enferm. 2017;38(1):1-7. doi: 10.1590/1983-1447.2017.01.63158

16. Meireles MV, Pascom ARP, Duarte EC. Factors associated with early virological response in hiv-infected individuals starting antirretroviral therapy in Brazil (2014-2015): results from a large HIV surveillance cohort. J Acquir Immune Defic Syndr. 2018;78(4):19-27. doi: 10.1097/ QAI.0000000000001684

17. Berhan Y, Berhan A. A meta-analysis of risk sexual behavior among male youth in developing countries. AIDS Res Treat. 2015;(1):1-9. doi: $10.1155 / 2015 / 580961$

18. Poulin M, Dovel K, Watkins SC. Men with Money and the "Vulnerable Women" client category in an AIDS epidemic. World Develop. 2016;85(1):16-30. doi: 10.1016/j.worlddev.2016.04.008

19. Tavares VO, Teixeira KD, Wajnman S, Loreto MDS. Interfaces entre a renda dos idosos aposentados rurais e o contexto familiar. Textos Contextos (Porto Alegre) [Internet]. 2011[cited 2018 Apr 18];10(1):94-108. Available from: http://revistaseletronicas.pucrs.br/ojs/index.php/ fass/article/view/8725/6427

20. Pillay-van WV, Bradshaw D. Mortality and socioeconomic status: the vicious cycle between poverty and ill health. Lancet Glob Health. 2017;5(9):851-52. doi: 10.1016/S2214-109X(17)30304-2

21. Probst C, Parry CD, Rehm J. Socio-economic differences in HIV/AIDS mortality in South Africa. Trop Med Int Health. 2016;21(7):846-55. doi: 10.1111/tmi.12712

22. Kabudula CW, Houle B, Collinson MA, Kahn K, Gómez-Olivé FX, Tollman S, et al. Socioeconomic differences in mortality in the antiretroviral therapy era in Agincourt, rural South Africa, 2001-13: a population surveillance analysis. Lancet Glob Health. 2017;5(9):924-35. doi: 10.1016/ S2214-109X(17)30297-8

23. Instituto Brasileiro de Geografia e Estatística (IBGE). Síntese de indicadores sociais: uma análise das condições de vida da população brasileira [Internet]. Brasília (DF): IBGE; 2017[cited 2018 Mar 20]. Available from: https://biblioteca.ibge.gov.br/visualizacao/livros/liv98965.pdf

24. Zeglin RJ, Stein JP. Social determinants of health predict state incidence of HIV and AIDS: a short report. AIDS Care. 2015;27(2):255-9. doi: $10.1080 / 09540121.2014 .954983$

25. Teye-Kau M, Tenkorang EY, Adjei PB. Revisiting the housing-health relationship for HIV-positive persons: qualitative evidence from the Lower Manya Krobo District, Ghana. Qual Health Res. 2018;28(8):1217-28. doi: 10.1177/1049732318764646

26. Tenkorang EY, Owusu AY, Laar AK. Housing and health outcomes of persons living with HIV/AIDS (PLWHAs) in the lower Manya Krobo District, Ghana. J Health Care Poor Underserved. 2017;28(1):191-215. doi: 10.1353/hpu.2017.0017

27. Parkhurst JO. Understanding the correlations between wealth, poverty and human immunodeficiency virus infection in African countries. Bull World Health Organ. 2010;88(7):519-26. doi: 10.2471/BLT.09.070185 
28. Organização das Nações Unidas (ONU). Human Development Report 2015: Work for Human Development [Internet]. New York: ONU; 2015 [cited $2018 \mathrm{Mar}$ 20]. Available from: http://hdr.undp.org/sites/default/files/2015_human_development_report_0.pdf

29. Programa das Nações Unidas para o Desenvolvimento (PNUD). Atlas do Desenvolvimento Humano 2013 [Internet]. Brasília (DF): PNUD; 2013 [cited 2018 mar 20]. Available from: http://atlasbrasil.org.br/2013/ 